\title{
Improving Political Behavior Through Group Counseling Services with Sociodrama Techniques in Schools
}

\author{
* M F Ilhamuddin ${ }^{1}$, I B Alisyahbana ${ }^{2}$ \\ 1Department of Counseling and Guidance, Faculty of Educational Science, Universitas Negeri Surabaya, Indonesia \\ 2Department of Counseling and Guidance Postgraduate, Universitas Negeri Surabaya, Indonesia
}

\begin{tabular}{l} 
Article Info \\
\hline Article history: \\
Received December 1, 2020 \\
Revised December 8, 2020 \\
Accepted December 20, 2020 \\
Available Online December 21, 2020 \\
\hline
\end{tabular}

Keywords:

Courteous Polite Behavior

Group Guidance

Sociodrama Technique

\begin{abstract}
Sociodrama technique is a method of role-playing learning to solve problems related to social phenomena. The use of sociodrama techniques in this study is to improve the polite behavior of students through group guidance services. This study uses action research, with two cycles, namely cycle 1 and 2 , each of which has two meetings and at each meeting allocates 40 minutes. Data collection methods used are observation, interviews, and documentation to determine the level of politeness of students in the implementation of group guidance services in school. The subjects of the study were ten students from grade 8th, Unesa Middle School who had problems in their polite behavior. Based on the observations of students in both cycles, there is an increase in the politeness of students, including good criteria in the implementation of group guidance services using Sociodrama techniques. After the implementation of the first cycle, it can be seen that there is a $63 \%$ change in students' behavior which means it shows the politeness behavior of students in the Good Criteria. At the meeting, after the second cycle, there is an increase to $76 \%$ in the Good criteria. Thus, from the results of the analysis, it can be concluded that the action research hypothesis that reads "The use of sociodrama techniques can improve polite behavior of students through the implementation of group guidance services in School " can be accepted so that it can be implied as an alternative and reference in providing guidance services to students or children.
\end{abstract}

\section{INTRODUCTION}

Education is dynamic, which changes with the times (Mubarok et al., 2020) and takes various forms. One form of formal educational institutions is school (Supriyanto et al., 2018). Schooling is a place where a person gets education, teaching, and character in dealing with other people so that there is a reciprocal process that occurs (Burchinal et al., 2010; Putra \& Astuti, 2019; Rantiyan, 2014). In the current era of globalization, the flow of information is so fast entering from various kinds of media where this information flow is not filtered. All human beings can freely access it without age limits, such as television, mass media, and the Internet. Through various kinds of social media, students will be able to learn independently. Students will learn freely to learn according to what they want to know (Abidah et al., 2020) through various kinds of information.

The flow of information is increasingly making people's perspectives and behavior change, gradually leaving the actual behavior of the Indonesian nation's ancestors. Behavior changes are very pronounced among teenagers (Susanto \& Aman, 2016). Adolescents who are still in school should have positive behavior because they are still in the process of education in character building, but in line with the influence of television, internet, magazines, pornographic images, 
and many others that are very easily accessible to teenagers, hurt adolescent behavior. If this is allowed to continue, it can damage the development of the nation's next generation.

The negative impact of the free flow of information can already be felt on changes in the behavior of school students, especially at the junior high school level, students often commit acts that are sometimes inappropriate and impolite towards teachers and friends (Farhatilwardah et al., 2019), through behavior that does not have courtesy ethics and from inappropriate words spoken by a student (Arianto el al., 2015).

Manners can be defined as the behavior of someone who upholds the values of respect, respect, is not arrogant, and has a noble character (Aroma \& Suminar, 2012). The embodiment or embodiment of this polite attitude is behavior that respects others through communication using language that does not belittle or belittle others. In Javanese culture, one of the polite attitudes is characterized by respectful behavior towards older people, using polite language, not having an arrogant nature (Aviyah \& Farid, 2014; Arianto et al., 2015; Aroma \& Suminar, 2012).

The observations that the researchers made while in school, of the 29 students, ten students were indicated to have poor manners. A phenomenon that occurs in schools, especially in schools, many students do not understand polite behavior, especially in the school environment. The case card pieces of evidence, many students say dirty, and it is not appropriate for a student to say it to his friend (Dewi et al., 2013). In addition to the case with teachers, many teachers complain about the polite behavior of students, they cannot speak politely with their teachers (Arianto et al., 2015), they consider talking to the teacher the same as talking to friends, and when meeting teachers, they pass by and do not show good manners when meeting a teacher (Malihah \& Alfiasari, 2018).

Researchers see the reality in schools, especially in schools, many students behave less politely in socializing either in communicating with teachers or with friends. As is done by many students, when asked to talk either with the teacher or with friends the answer is not using good language and students often say dirty with students of the opposite sex (Praptiani, 2013). The reason for the emergence of students' lack of courtesy is the lack of understanding of students about polite behavior, mostly courtesy in the school environment.

The counseling teacher, in this case, has the task of shaping the character of students (Roshita, 2015). In this case, the changed behavior is the polite behavior of students in their interactions. In changing the behavior of students who have disrespectful behavior, BK has various types of services that can be used to help students shape polite behavior (Sentana \& Kummala, 2015; Roshita, 2015). Counseling services at schools/madrasahs are an effort to assist students in the development of their personal lives, social life, learning activities, and career planning and development.

Counseling services facilitate the development of students, individually, in groups, and or classically, according to their needs, potentials, talents, interests, development, conditions, and opportunities. This service also helps overcome weaknesses and obstacles as well as problems faced by students at school (Purwoko, 2017). Types of counseling services include orientation services, information services, placement and distribution services, content mastery services, individual counseling services, group guidance services (Liberati \& Braon, 2018; Mester et al., 2017), group counseling services, consulting services, mediation services and advocacy services (Prayitno, 2012; Bulantika, 2019; Tastan et al., 2018; Tate et al., 2017).

Here services that can be used to shape polite behavior, researchers use group guidance services (Indul \& Lianawati, 2020). The reason researchers use group guidance services is due to the less optimal classical guidance services that have been provided by researchers in previous guidance services. Group guidance services are services that help students in personal development, social relationship skills (Isti'adah \& Arumsari, 2020), learning activities, careers/positions, and decision making, as well as carrying out certain activities through group dynamics (Yusop et al., 2018; Bulantika 2019). In carrying out group guidance services, researchers used sociodrama techniques (Sari, 2013; Ita, 2015; Indul \& Lianawati, 2020). Winkel (1991) explains that sociodrama is a dramatization of the problems that can arise in association 
with other people, including conflicts experienced in social interactions. This opinion can be interpreted that the sociodrama technique is one of the techniques used to provide group guidance services in schools by applying behaviors related to social problems.

The choice of the use of the sociodrama technique is based on the reason that the problems that arise are related to social problems, namely lack of ethical manners concerning the surrounding environment, especially with the school environment so that sociodrama is considered appropriate to improve courtesy. Through sociodrama techniques, students will learn to behave politely and politely to others in the form of playing a role. This technique trains students to behave politely with other people both in the family, school and in the community.

\section{RESEARCH METHOD}

This research is an Action Research Guidance and Counseling, which is applied in schools with a total of 10 students. This research begins with the need assessment stage of students, and observations of classical guidance service activities on polite behavior of students. The results of the need assessment are used to make action research steps for guidance and counseling. The action research used is a research model from Kemmis and Mc. Taggart (1999).

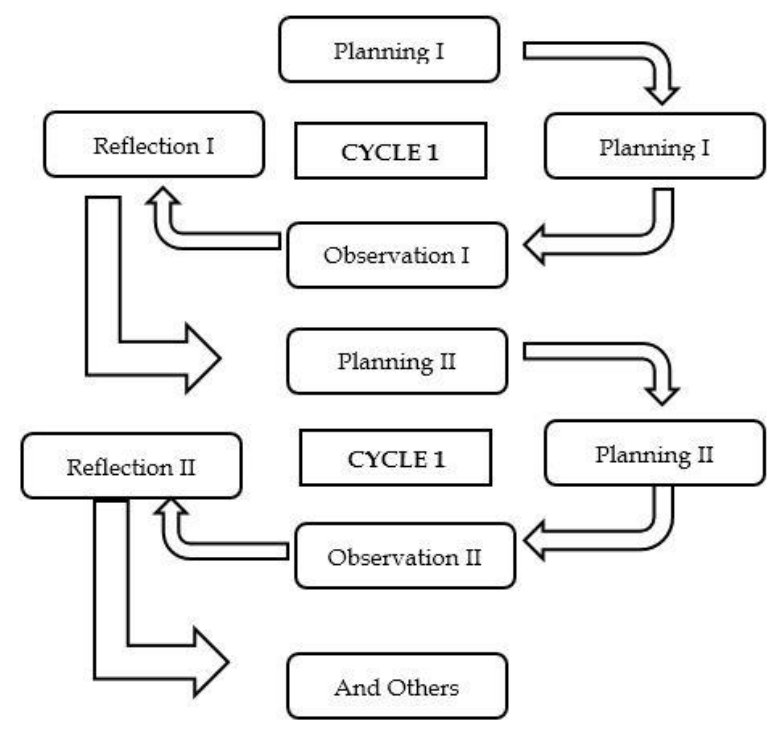

Figure 1. Classroom Action Research Model Kemmis \& Mc Taggart Model (1999).

Based on Figure 1 to describes the design research cycle. This action research was conducted in the form of a cycle; the cycle designed in this action research was two cycles. Each cycle consists of one or two meetings. Each cycle has stages, namely: (1) planning, (2) action, (3) observation / observation, and (4) reflection. After one cycle is carried out, then prepare a re-planning for the cycle based on the results of observations in cycle one. The cycle is a model of Kemmis and Mc. Taggart.

Based on the action research design, the research instruments are as follows: 1) plan for implementing group guidance services, 2) observation sheets, and 3) interview sheets. This research uses descriptive analysis of quantitative data and qualitative data collected through data collection techniques. The data analysis technique used is to analyze the observation sheet and the interview sheet. This study is said to be successful if: 1) the behavior of the students' courtesy is categorized as increased and successful if the results of observations and interviews on the disrespectful behavior of students reach a score above the low score limit. 2) The response of students' activities in participating in group guidance activities reaches a minimum completeness limit of 70\% with good categories, and 3) The activities of students have increased from cycle 1 and cycle 2 at least $5 \%$. 


\section{RESULTS AND DISCUSSION Research Results Cycle 1}

\section{Planning}

Planning is carried out by researchers by preparing guidance and counseling tools, guidance materials, sociodrama texts, tools and materials, observation sheets, interview sheets, and data analysis.

\section{Execution or Action}

The implementation is by the procedures planned in the RPLBK. Meanwhile, collaborators/peers act as observers and provide suggestions or input for the development of the next group guidance process. In this study, the researcher made observations on 10 students who in the pre-cycle had low courtesy scores. There are 9 items of observation of disrespectful behavior, and students are said to have high courtesy when students have low scores. The results of the cycle 1 observations regarding the disrespectful behavior shown by 10 students are described in the following table:

Table 1. Observation Results of Cycle 1

\begin{tabular}{llrlcc}
\hline No & Name & Pre Test & Category & $\begin{array}{c}\text { Cycle 1 test } \\
\text { results }\end{array}$ & Category \\
\hline 1 & Afna & 3 & Moderate & 2 & Low \\
\hline 2 & Ardi & 3 & Moderate & 1 & Low \\
\hline 3 & Cara & 4 & Moderate & 2 & Low \\
\hline 4 & Eli & 3 & Moderate & 1 & Low \\
\hline 5 & Alwi & 4 & Moderate & 1 & Low \\
\hline 6 & Hil & 5 & Moderate & 3 & Low \\
\hline 7 & Sat & 3 & Moderate & - & Low \\
\hline 8 & Oliv & 3 & Moderate & 1 & Low \\
\hline 9 & Rahma & 4 & Moderate & 1 & Low \\
\hline 10 & Ridho & 3 & Moderate & - & Low \\
\hline
\end{tabular}

From Table 1 it can be seen that the score of the students' polite behavior after being given a group guidance action research using the sociodrama technique in the first cycle has not reached the maximum value according to the target.

\section{Observation or Observation}

Observation activities are carried out by collaborators / peers by observing researchers and the development of students during group guidance activities using the sociodrama technique. Collaborators / peers fill out the observation sheets provided by the researcher. The percentage of the observation sheet in cycle I is as follows:

Table 2. Observation Percentage of Group Guidance Activities with Sociodrama Techniques

\begin{tabular}{clccc}
\hline No & \multicolumn{1}{c}{ Observed aspects } & \% & Category \\
\hline 1 & Active in service activities & 23 & 58 & Moderate \\
\hline 2 & Cooperate with friends & 28 & 70 & Good \\
\hline 3 & Express opinions on your own initiative & 22 & 55 & Moderate \\
\hline $\begin{array}{l}\text { Appreciate friends who are having an } \\
\text { opinion. }\end{array}$ & 26 & 65 & Good \\
\hline $\begin{array}{l}\text { Complete assignments given by the } \\
\text { teacher }\end{array}$ & 27 & 68 & Good \\
\hline Persentase & 126 & 63 & Good \\
\hline
\end{tabular}

Based on Table 2 above, according to collaborators / peers, it is stated that the development of group guidance activities with the sociodrama technique carried out by researchers through observation sheets has not reached the minimum limit in cycle 1, namely the percentage of 
development in group guidance activities reaches $60 \%$ and the percentage of observation of group guidance activities is equal to $70 \%$.

\section{Reflection}

In this process, the researcher evaluates the overall implementation of the process of providing group guidance services, from the success of the activity to the obstacles faced. This stage is used to determine the planning for the next cycle. At this reflection stage, some of the evaluations carried out are:

\section{1) Process Evaluation}

The implementation of group guidance services using the sociodrama technique is carried out 2 meetings in one cycle. Although only 2 meetings were held, they were carried out smoothly. Although the results of observations of student activity indicate that the level of activity is in good criteria, some aspects are not implemented by students, for example, students are still reluctant to ask the teacher about guidance material and students are still reluctant to express their opinions based on their initiative alone.

\section{2) Evaluation of Results for Sub section 1}

From the implementation of group guidance services using the sociodrama technique, besides the results of process evaluation, an evaluation of the results of the implementation of classical guidance services is also obtained. The results of this research activity are changes in the behavior of students towards teachers being polite at school. Students who initially did not behave politely became polite, especially to teachers. The results of this research action were obtained from interviews with subject teachers, homeroom teachers, and class leaders. Evaluation of the results of the implementation of the action is also seen from the results of observations of students in class. In the results of observations on August 31, 2018 by observers in class grade $8^{\text {th }} \mathrm{B}$, data was obtained about disrespectful behavior that was still raised by some students.

Table 3. Data Table of Indecent Behavior

\begin{tabular}{clc}
\hline No & \multicolumn{1}{c}{ Emerging Behavior } & Number of Students \\
\hline 1 & Leave class without permission & 23 \\
\hline 2 & Crowded in class & 28 \\
\hline 3 & Always moving seats & 22 \\
\hline \multicolumn{2}{l}{ Talk to friends while the teacher explains } \\
4 & the lesson. & 26 \\
\hline
\end{tabular}

From the data above, it can be seen that after the implementation of classroom guidance action research in cycle 1 there were still some students who still showed disrespectful behavior. Due to this, the researcher decided to continue the action to cycle 2 . In cycle 2 the researcher slightly modified the implementation of the sociodrama technique. It is hoped that after the implementation of the action will be continued in cycle 2, there will be no more disrespectful behavior raised by students.

\section{Recommendations of Cycle 1}

The development of polite behavior of students in cycle I showed an increase. However, there are still some shortcomings that need to be corrected in the implementation of group guidance activities using the sociodrama technique, including the following:

1. Researcher's ability to manage groups

2. Choosing the right time and place so that group guidance activities run smoothly and achieve the expected goals.

3. Improvements to the sociodrama rules that were not previously understood by group members, in cycle II it needs to be re-explained.

4. Motivation of group members who is still low in participating in group guidance activities needs to be improved. 
Based on the results of the implementation and evaluation of group guidance in cycle 1, it can be concluded that the implementation of group guidance in cycle 1 still has shortcomings as described in the results of reflection in cycle 1 and has not reached the target expected by the researcher. Reflection in cycle 1 becomes a reference for implementing actions in cycle 2 . The adoption to carry out this second cycle is in line with the research of Susanti et al., (2019) which found that in cycle I only obtained a classical completeness proportion of $40 \%$ so that the second planning cycle so that in cycle 2 it achieved $83 \%$ classical completeness. While in this study the proportion of cycle 1 was $63 \%$. So it requires a second cycle to produce a higher increase.

\section{Research Cycle 2}

\section{Planning}

Planning in cycle 2 is preparing guidance and counseling tools, such as RPLBK, guidance materials, role-playing scripts, tools and materials, observation sheets, and data analysis. Making improvements from deficiencies in cycle 1 by increasing the readiness of researchers in managing groups and providing motivation to group members to be more active and enthusiastic in participating in group guidance activities using the sociodrama technique.

\section{Execution or Action}

At this stage, the implementation of the action in the form of group guidance services uses the sociodrama technique. The implementation of this second cycle was carried out in 2 meetings, for $1 \times 40$ minutes. The implementation of actions that the researcher will take are adjusted to the results of the evaluation and reflection in cycle I which have been formulated in the Service Implementation Plan. Collaborators or peers carry out their duties as observers and provide suggestions or input for the development of the implementation of group guidance using the sociodrama technique. Data collection and data analysis in the second cycle using the results of observations and interviews.

The results of observations are used to determine the level of polite behavior of students compared to the results of observations before taking action and after being given action. The results of the observations are explained in the table as follows:

Table 4. Observation Results in Cycle 2

\begin{tabular}{llcccc}
\hline No & Name & Post-test 1 & Category & Post-test 2 & Category \\
\hline 1 & $\mathrm{Af}$ & 2 & Low & 1 & Low \\
\hline 2 & $\mathrm{Ar}$ & 1 & Low & - & Low \\
\hline 3 & $\mathrm{Ca}$ & 2 & Low & - & Low \\
\hline 4 & $\mathrm{El}$ & 1 & Low & - & Low \\
\hline 5 & $\mathrm{Al}$ & 1 & Low & 1 & Low \\
\hline 6 & $\mathrm{Hi}$ & 3 & Low & - & Low \\
\hline 7 & $\mathrm{Sa}$ & - & Low & - & Low \\
\hline 8 & $\mathrm{Ol}$ & 1 & Low & - & Low \\
\hline 9 & $\mathrm{Ra}$ & 1 & Low & - & Low \\
\hline 10 & $\mathrm{Ri}$ & - & Low & - & Low \\
\hline
\end{tabular}

From the data above, it can be seen that after the implementation of classroom guidance action research in cycle 2 there were still some students who still showed disrespectful behavior. However, there was a decline from cycle 1, wherein cycle 1 yesterday, there were still about 8 students who showed disrespectful behavior. Whereas in the second cycle there were only 2 students who showed disrespectful behavior. Due to time constraints, the researchers collaborated with the bk teachers in schools. to give or continue actions to eliminate disrespectful behavior, so that it is hoped that all rude behavior will no longer exist in the school.

The comparison of the development of the increase in the polite behavior of students above can be seen from the following diagram: 


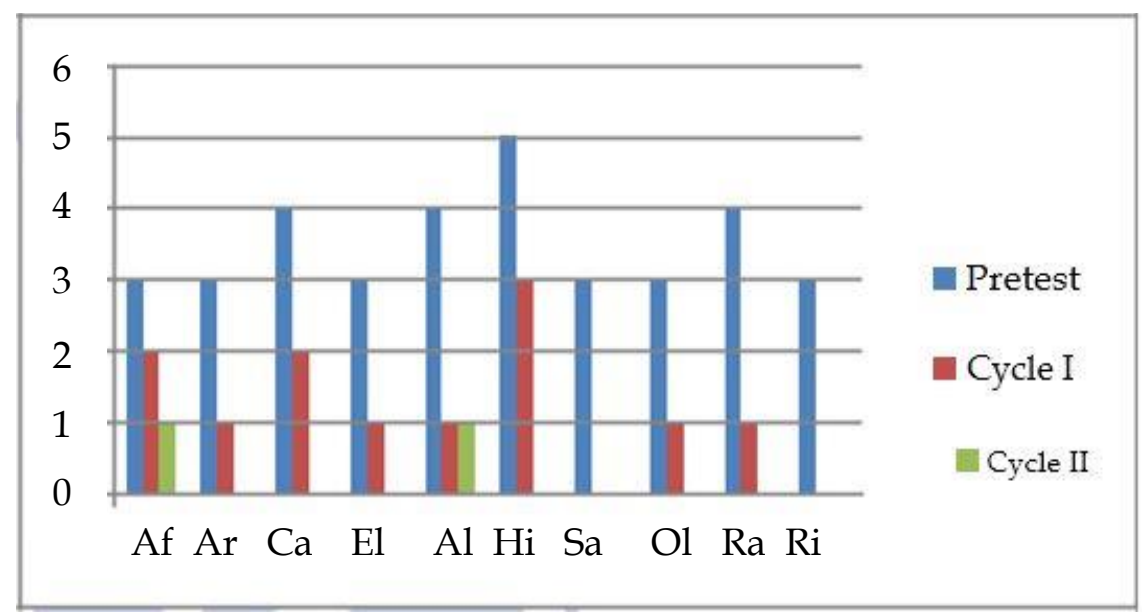

Figure 2. Comparison diagram of the improvement in the results of observing polite behavior

The diagram above shows that the decline in students' disrespectful behavior from the results of observations before being given action and after being given action in cycle I and cycle II. This is consistent with Sari (2013) that there is a significant result output $=0.00<5 \%$, which means that there is a significant difference between students' prosocial attitudes before being given treatment (pre-test) and after treatment (post-test). One of the efforts that need to be made to help students improve prosocial attitudes is by optimizing group guidance (Indul \& Lianawati, 2020; Ita, 2015; Sari, 2013).

\section{Observation or Observation}

Observation activities are carried out by collaborators / peers by observing researchers and the development of students during group guidance activities using the sociodrama technique. Collaborators / peers fill out the observation sheets provided by the researcher. The percentage of the observation sheet in cycle 2 is as follows:

Table 5. Observation Percentage of Group Guidance Activities with Sociodrama Techniques in Cycle 2.

\begin{tabular}{llccc}
\hline No & \multicolumn{1}{c}{ Observed aspects } & \% & Category \\
\hline 1 Active in service activities & 30 & 75 & Good \\
\hline 2 Cooperate with friends & 31 & 78 & Good \\
\hline 3 Express opinions on your own initiative & 30 & 75 & Good \\
\hline $\begin{array}{l}\text { Appreciate friends who are having an } \\
\text { opinion. }\end{array}$ & 30 & 75 & Good \\
\hline $\begin{array}{l}\text { Complete assignments given by the } \\
\text { teacher }\end{array}$ & 30 & 75 & Good \\
\hline Persentase & $\mathbf{1 5 1}$ & $\mathbf{7 6}$ & Good \\
\hline
\end{tabular}

From the table above, it can be seen that the results of observations of students show the number of $76 \%$ Then the activeness of students in following group guidance reaches the good Criteria. This is because students can focus more when participating in guidance activities. In the activity of appreciating friends, they think that they get a good category This is in line with Roshita's (2015) research which states that through group guidance services students have good and polite attitudes. All group members can express opinions, ask questions, and answer their own will. In expressing opinions through group guidance it will be easier to improve student communication (Adhityaputra, 2015; Qomari, 2016; Ramaraju, 2012).

This is supported by the addition of Puzzle games activities which make students more enthusiastic in discussing polite and polite behavior. In group guidance service activities using sociodrama techniques added to role playing activities and puzzles, students are very 
enthusiastic about following group guidance services to completion. Students are brave and actively discuss the behavior they play.

\section{Reflection}

In this process, the researcher evaluates the overall implementation of the process of providing group guidance services, from the success of the activity to the obstacles faced. At this reflection stage, some of the evaluations carried out are:

\section{1) Process Evaluation}

The implementation of group guidance services using the sociodrama technique is carried out in 2 meetings in one cycle. Although only 2 meetings were held, they were carried out smoothly. The results of observations in the second cycle, it appears that students have increased in all indicators. Although still in the good category, almost all group members experienced an increase in all indicators.

\section{2) Evaluation of Results}

From the implementation of group guidance services using the sociodrama technique, besides the results of process evaluation, an evaluation of the results of the implementation of classical guidance services is also obtained. The results of this research activity are changes in the behavior of students towards teachers being polite at school. Students who initially did not behave politely became polite, especially to teachers. The results of this research action were obtained from the results of interviews with subject teachers, homeroom teachers, and class leaders. In line with the research by Puspitasai et al., (2020) that it is necessary to provide research in cycle II to be able to improve student attitudes in learning. Students will increase the increase in good results in behavior and behavior in learning after being given in cycle 2 (Herzamzam \& Rahmad, 2020; Supriyanto et al., 2020).

Evaluation of the results of the implementation of the action is also seen from the results of observations of students in the class. In the results of observations on October 21, 2020, by observers at school, data were obtained about disrespectful behavior that was still raised by some students.

Table 6. Data Table on Disrespectful Behavior Cycle 2

\begin{tabular}{clc}
\hline No & \multicolumn{1}{c}{ Emerging Behavior } & Number of Students \\
\hline 1 & Leave class without permission & - \\
\hline 2 & Crowded in class & - \\
\hline 3 & Always moving seats & - \\
\hline & $\begin{array}{l}\text { Talk to friends while the teacher explains } \\
4\end{array}$ the lesson. & 1 \\
\hline
\end{tabular}

From the data above, it can be seen that after the implementation of ptbk in cycle 2 there were still some students who still showed disrespectful behavior. However, there was a decline from cycle 1 , wherein cycle 1 yesterday, there were still about 4 disrespectful behaviors raised by some students. Whereas in the second cycle there was only 1 disrespectful behavior that was still raised by students. Due to time constraints, researchers collaborated with counseling teachers at schools to give or continue actions to eliminate disrespectful behavior, so it is hoped that all disrespectful behavior will no longer exist in the school.

\section{Recommendations of Cycle 2 for Sub section 2}

The results of reflection in the second cycle showed that there was a decrease in the disrespectful behavior of students in the second cycle. This is indicated by a decrease in the percentage results of students' disrespectful behavior and an increase in the percentage of activeness in group guidance activities using the sociodrama technique.

The development of the courtesy behavior of students in cycle I showed an increase of $63 \%$ and in cycle II 76\% with the good category. So that group guidance activities with the Soiodrama 
technique are effective for improving the polite behavior of students. This is in line with research from Indul \& Lianawati, (2020) which states that sociodrama techniques can improve students' interactive social skills in group guidance in class. Also, through sociodrama techniques, students can develop interpersonal communication skills when speaking (Isti'adah \& Arumsari 2020), in this case, it can be possible when students can manage their speaking skills well, they will be trained to be polite too.

From the description above, the researchers and collaborators/peers decided that cycle II was the last cycle in this study. Apart from time constraints, this is also because the second cycle has reached the achievement indicators set by the researcher, namely from low scores increasing to medium or high. Whereas in group guidance activities that have been implemented, the percentage of student and researcher activities has increased in each cycle.

\section{CONCLUSION}

Based on the results of research and discussion, the results of research to improve the polite behavior of students through group guidance with sociodrama techniques in schools, the following conclusions can be drawn. In the initial conditions, after implementing classical guidance with courtesy material to teachers, some students who received this material did not experience changes in their behavior at school. This shows that the objectives of classical guidance services are not achieved. To achieve service objectives, action research in guidance and counseling was carried out by conducting group guidance services using sociodrama techniques. The use of the sociodrama technique is a tool to support the implementation of group guidance. By playing sosidrama, students will act out scenes related to courtesy.

In this study, in cycle 1 the sociodrama technique was used as material for group discussions. The behaviors that are played are then discussed by students. But in cycle 1, the results of the study were not optimal because not all students experienced changes in behavior, namely polite behavior towards the teacher. This is because students do not focus and do not actively participate in group discussions. Based on the results of the actions in cycle 1, in cycle 2 the implementation of group guidance was carried out by modifying scenarios or sociodrama scripts and also adding group activities in the form of puzzle games. This aims to make students more interested and enthusiastic about following group guidance. Before conducting the discussion, students play a role in accordance with the behaviors listed in the drama script. After playing the role of the other groups, they take turns responding to the actions of the group. In cycle 2, according to the results of observations, students actively participated in classical guidance services, from the research results also obtained changes in student behavior to be more polite. This is evidenced by observations and interviews with homeroom teachers, subject teachers, and class leaders.

From action research in guidance and counseling through the use of sociodrama techniques in group guidance services, it can improve students' polite behavior in schools. From the behavior of students who have increased it can be seen that sociodrama techniques are effectively used in group guidance services. The research that can be used is only limited to 10 students who are used as research subjects because this research is a classroom action research that cannot be generalized. This is because it is only related to students in certain classes. To overcome this problem, further research can be carried out using the implementation of the implementation or application so that it can be generalized to students who have almost the same behavior, so that it can be implied as an alternative and reference in providing guidance services to students or children.

\section{ACKNOWLEDGEMENTS}

The researchers are grateful to all parties who have supported the implementation of this research. 


\section{REFERENCES}

Abidah, A., Hidaayatullaah, H. N., Simamora, R. M., Fehabutar, D., \& Mutakinati, L. (2020). The impact of covid-19 to indonesian education and its relation to the philosophy of "Merdeka Belajar". Studies in Philosophy of Science and Education, 1(1), 38-49.

Adhityaputra, V. (2015). Efektivitas teknik permainan untuk meningkatkan keterampilan komunikasi interpersonal pada remaja. Jurnal Ilmu Pendidikan dan Pengajaran. 2(3), 290-298.

Arianto, K. N., Hasyim, A., \& Yanzi, H. (2015). Pengaruh lingkungan sosial terhadap adab sopan santun pada siswa kelas X. Jurnal Kultur Demokrasi, 3(8).

Aroma, I. S., \& Suminar, D. R. (2012). Hubungan antara tingkat kontrol diri dengan kecenderungan perilaku kenakalan remaja. Jurnal Psikologi Pendidikan dan Perkembangan, 1(2), $1-6$.

Aviyah, E., \& Farid, M. (2014). Religiulitas, kontrol diri, dan kenakalan remaja. Jurnal Psikologi Indonesia, 3(2), 126-129.

Brown, S. W., Grant, A. M. (2010). From grow to group: Theoretical issues and a practical model for group coaching in organisations. An International Journal of Theory, Research and Practice, $3,30-45$.

Bulantika, S. Z. (2019). Effect of counselor competence on student interest in group guidance services. Jurnal Bimbingan Konseling, 5(1), 50-63.

Burchinal, M., Vandergrift, N., Pianta, R., Mashburn, A. (2010). Threshold analysis of association between child care quality and child outcomes for low income children in pre-kindergarten programs. Early Childhood Research Quarterly, 25, 166-176.

Dewi, A. C. K., Suandi, N., \& Martha, N. (2013). Tuturan remaja di kalangan pelajar anak multietnis (Indonesia-asing) pada SMP swasta se-kecamatan Kuta, badung: sebuah kajian kesantunan dalam tindak tutur. Jurnal Pendidikan dan Pembelajaran Bahasa Indonesia, 2.

Indul, M. A., \& Lianawati, A. (2020). Bimbingan kelompok teknik sosiodrama efektif untuk meningkatkan interaksi sosial siswa Kelas X SMA Antartika Sidoarjo. Jurnal Bimbingan dan Konseling, 4(2), 300-305.

Isti' adah, F. N \& Arumsari, C. (2020). Efektivitas bimbingan kelompok melalui teknik sosiodrama dalam mengembangkan komunikasi interpersonal siswa. Quanta, 4(3), 126-132.

Ita, R. (2015). Upaya meningkatkan perilaku sopan santun melalui layanan bimbingan kelompok dengan teknik sosiodrama. Jurnal Penelitian Tindakan Bimbingan dan Konseling, 1(2), 29-35.

Kemmis S., \& McTaggart, R. (1998). The action research planner. Deaking university.

Liberati, R., \& Braun, E. (2018). Counselor competence with male body image disturbance. Alabama Counseling Association Journal, 42(2).

Malihah, Z., \& Alfiasari, A. (2018). Perilaku cyberbullying pada remaja dan kaitannya dengan kontrol diri dan komunikasi orang tua. Jurnal Ilmu Keluarga dan Konsumen, 11(2), 145-156.

Mesters, I., van Keulen, H. M., de Vries, H., \& Brug, J. (2017). Counselor competence for telephone motivation interviewing addressing lifestyle change among Dutch older adults. Evaluation and Program Planning, 65, 47-53.

Mubarok, H., Safitri, N. S., \& Adam , A. S. (2020). The novelty of religion and art: Should we combine with stem education?. Studies in Philosophy of Science and Education, 1(3), 97-103.

Praptiani, S. (2013). Pengaruh kontrol diri terhadap agresivitas remaja dalam menghadapi konflik sebaya dan pemaknaan gender. Jurnal Sains Dan Praktik Psikologi, 1(1).

Purwoko, B., \& Fitriyah, F. K. (2017). Narcissism and aggression in counselor candidates: A challenge for counselor education in Indonesia. 9th International Conference for Science Educators and Teachers (ICSET 2017). Atlantis Press. 
Puspitasari, W. F., Martaningsih, S. T., \& Sukardi. (2020). Peningkatan motivasi dan hasil belajar pembelajaran daring pada siswa kelas 1 SD Negeri Turi 3 melalui media powerpoint. Prosiding Pendidikan Profesi Guru Fakultas Keguruan dan Ilmu pendidikan Universitas.

Qomari. (2016). Meningkatkan keterampilan komunikasi interpersonal dengan bimbingan kelompok dengan teknik permainan. Jurnal Penelitian Pendidikan Indonesia, 1(2), 37-42.

Ramaraju. S. (2012). Phychological perspective of interpersonal communication. Journal of Arts, Science, and Commerce, 3(4). 68-73.

Rantiyan. (2014). Meningkatkan motivasi belajar melalui bimbingan kelompok dengan teknik diskusi kelompok. Jurnal Penelitian Tindakan Kelas. 16(2).

Roshita. (2015). Upaya Meningkatkan perilaku sopan santun melalui layanan bimbingan kelompok dengan teknik sosiodrama. Jurnal Penelitian Tindakan Bimbingan dan Konseling, 1(2), 29-35.

Sari, E. P. (2013). Pengembangan model layanan bimbingan kelompok dengan teknik sosiodrama untuk meningkatkan sikap prososial. Jurnal Bimbingan Konseling, 2(2), 79-85.

Sentana, M. A., \& Kumala, I. D. (2017). Agresivitas dan kontrol diri remaja di Banda Aceh. Jurnal Sains Psikologi, 6(2), 51-55.

Supriyanto, A., Hartini, S., Irdasari, W. N., Miftahul, A., Oktapiana, S., \& Mumpuni, S. D. (2020). Teacher professional quality: counselling services with technology in pandemic covid-19. Jurnal Bimbingan dan Konseling, 10(2), 176-189.

Supriyanto, A., \& Wahyudi, A. (2018). Group guidance services based on folklore for students Junior High School. International Journal of Indonesian Education and Teaching, 2(1).

Susanti, E., Sutisnawati, A., \& Nurasiah, I. (2019). Penerapan Model Group Investigasi (GI) Untuk Meningkatkan Kemampuan Berfikir Kritis Siswa di Kelas Tinggi. Jurnal Utile, 5(2). 123-133.

Susanto, A. A. V., \& Aman. (2016). Pengaruh pola asuh orang tua, pergaulan teman sebaya, media televisi terhadap karakter siswa SMP. Jurnal Pendidikan IPS, 3(2), 105-111.

Tastan, S. B., Davoudi, S. M. M., Masalimova, A. R., Bersanov, A. S., Kurbanov, R. A., Boiarchuk, A. V, \& Pavlushin, A. A. (2018). The impacts of teacher's efficacy and motivation on student's academic achievement in science education among secondary and high school students. EURASIA Journal of Mathematics Science and Technology Education, 14(6), 2353-2366.

Tate, K. A., Bloom, M. L., Tassara, M. H., \& Caperton, W. (2017). Counselor Competence, Performance Assessment, and Program Evaluation. Measurement and Evaluation in Counseling and Development, 47(4), 291-306.

Yusop, Y. H. M., Zainudin, Z. N., \& Ismail, A. (2018). Effects of group guidance activities on students' self-concept. International Journal of Academic Research in Business and Social Sciences, $8(12), 1697-1707$.

\footnotetext{
Author (s):

* Muhammad Farid Ilhamuddin (Corresponding Author)

Department of Counseling and Guidance, Faculty of Educational Science,

Universitas Negeri Surabaya, Indonesia

Email: muhammadilhamuddin@unesa.ac.id
}

Issac Briyan Alisyahbana

Department of Counseling and Guidance Postgraduate,

Universitas Negeri Surabaya, Indonesia

Email: issac.19012@mhs.unesa.ac.id 